\title{
HILGARDIA
}

A Journal of Agricultural Science Published by the California Agricultural Experiment Station

$\begin{array}{lll}\text { VOLUME } 19 & \text { MARCH, } 1949 & \text { NUMBER } 2\end{array}$

\section{THE BIOLOGY OF THE STRAWBERRY ROOTWORM IN CALLFRNIA}

LESLIE M. SMITH AND GEORGE S. KIDO

\section{THE RASPBERRY LEAF SAWFLY}

LESLIE M. SMITH AND GEORGE S. KIDO

UNIVERSITY OF CALIFORNIA - BERKELEY, CALIFORNIA 


\section{CONTENTS}

THE BIOLOGY OF THE STRAWBERRY ROOTWORM IN CALIFORNIA-by Leslie M. Smith and George S. Kido

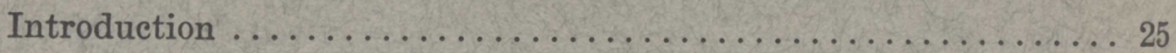

Geographical distribution $\ldots \ldots \ldots \ldots \ldots \ldots \ldots \ldots \ldots \ldots \ldots 25$

Seasonal cycle $. \ldots \ldots \ldots, \ldots \ldots \ldots \ldots \ldots \ldots \ldots \ldots \ldots \ldots .26$

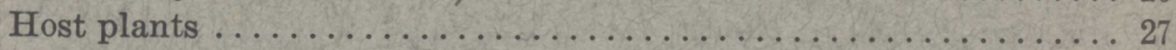

Adult stadium ............................. 27

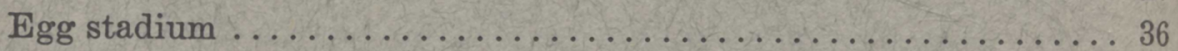

Larval stadium $\ldots \ldots \ldots \ldots \ldots \ldots \ldots \ldots \ldots \ldots \ldots \ldots \ldots . \ldots \ldots$

Pupal stadium ............................ 40

Summary .............................. 40

Literature eited $\ldots \ldots \ldots \ldots \ldots \ldots \ldots \ldots \ldots \ldots \ldots \ldots \ldots, 42$

\section{THE RASPBERRY LEAF SAWFLY-by Leslie M. Smith and} George S. Kido

Life history $\ldots \ldots \ldots \ldots \ldots \ldots \ldots \ldots \ldots \ldots \ldots \ldots \ldots . \ldots \ldots$

Seasonal history $\ldots \ldots \ldots \ldots \ldots \ldots \ldots \ldots \ldots \ldots \ldots \ldots \ldots .48$

Host plants. ........................... 50

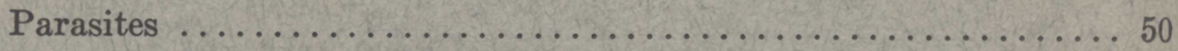

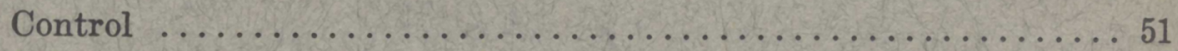

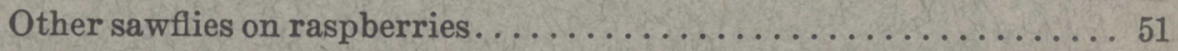

Literature cited $\ldots \ldots \ldots \ldots \ldots \ldots \ldots \ldots \ldots \ldots \ldots \ldots . . \ldots 4$ 


\section{THE RASPBERRY LEAF SAWFLY}

LESLIE M. SMITH AND GEORGE S. KIDO 



\section{THE RASPBERRY LEAF SAWFLY'}

\section{LESLIE M. SMITH ${ }^{2}$ AND GEORGE S. KIDO ${ }^{3}$}

THE RASPBERRY LEAF SAWFLY (Priophorus rubivorus Rohwer) ${ }^{4}$ has been present in California for a number of years. In the spring of 1928, the writers found it abundant and widely distributed in the central district of California. It undoubtedly was present there before 1928. Since bush-berry production in the central district was negligible until about 1916, this species could not have been a pest prior to that time.

In midwinter, when the planting stock of bush berries is transported as bare root plants, the sawfly occurs as prepupal larvae and pupae in cocoons in the soil. The chances that the insect will be brought into the state on planting stock consequently are slight. It seems more likely to be native to the Pacific Coast, probably living on wild bush berries prior to the extensive cultivation of horticultural varieties.

Published records indicate that distribution of the pest is limited to California, Oregon, and Washington. In Oregon, the species was described by S. A. Rohwer (1922) from a single female specimen collected on raspberry by E. J. Neweomer at Portland on August 10, 1917. In Washington, ${ }^{5}$ in 1937, two specimens were collected on Youngberry at Puyallup; and in 1938, damage to bush berries by this species was reported in the state (Hanson, 1938).

\section{LIFE HISTORY}

The eggs of the raspberry leaf sawfly are oval, shining, and opaque white. They measure 0.45 millimeter in width and 1.23 millimeters in length. The female is provided with a saw-type ovipositor which she uses to prepare a cavity in the petioles of leaves or in the tender bark of the new shoots. There she lays her eggs singly between the pith and the bark, placing them parallel to the surface of the bark with the long diameter parallel to the axis of the petiole. At San Jose, the incubation period of the egg ranged from 7 to 9 days under outdoor conditions in June.

The newly hatched larvae feed on the undersides of the leaves, cutting small, roughly circular holes between the veinlets. As they become larger the larvae (fig. 1) eat all the leaf tissue between the main veins. This produces large holes, which, by reason of the arrangement of the leaf veins, are frequently triangular (fig. 2). The larvae are solitary feeders and are always found on the lower side of the leaf. They prefer shade, and are always found in the center and low down in the hedgerow, more commonly on the shady side than on the sunny side. The length of the larval period was not determined experimentally, but field evidence indicates that it is from 4 to 6 weeks.

\footnotetext{
${ }^{1}$ Received for publication May 12, 1948.

${ }^{2}$ Associate Professor of Entomology and Associate Entomologist in the Experiment Station.

${ }^{3}$ Entomologist, Wisconsin Alumni Research Foundation.

" Determined by William Middleton.

${ }^{5}$ Personal communication from C. F. W. Muesebeck.
} 


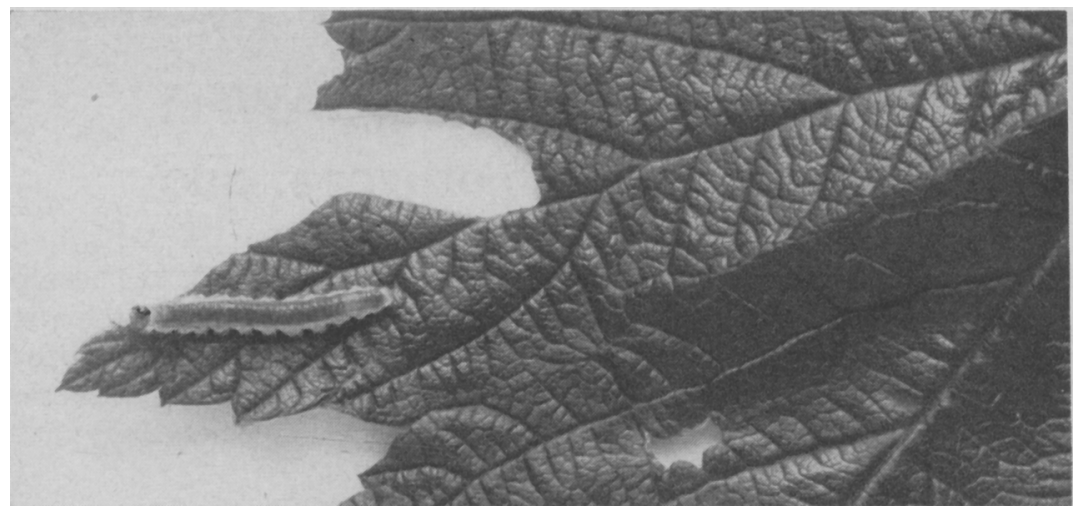

Fig. 1.-Raspberry leaf showing typical injury and feeding larvae of Priophorus rubivorus Rohwer. (Two times natural size.)

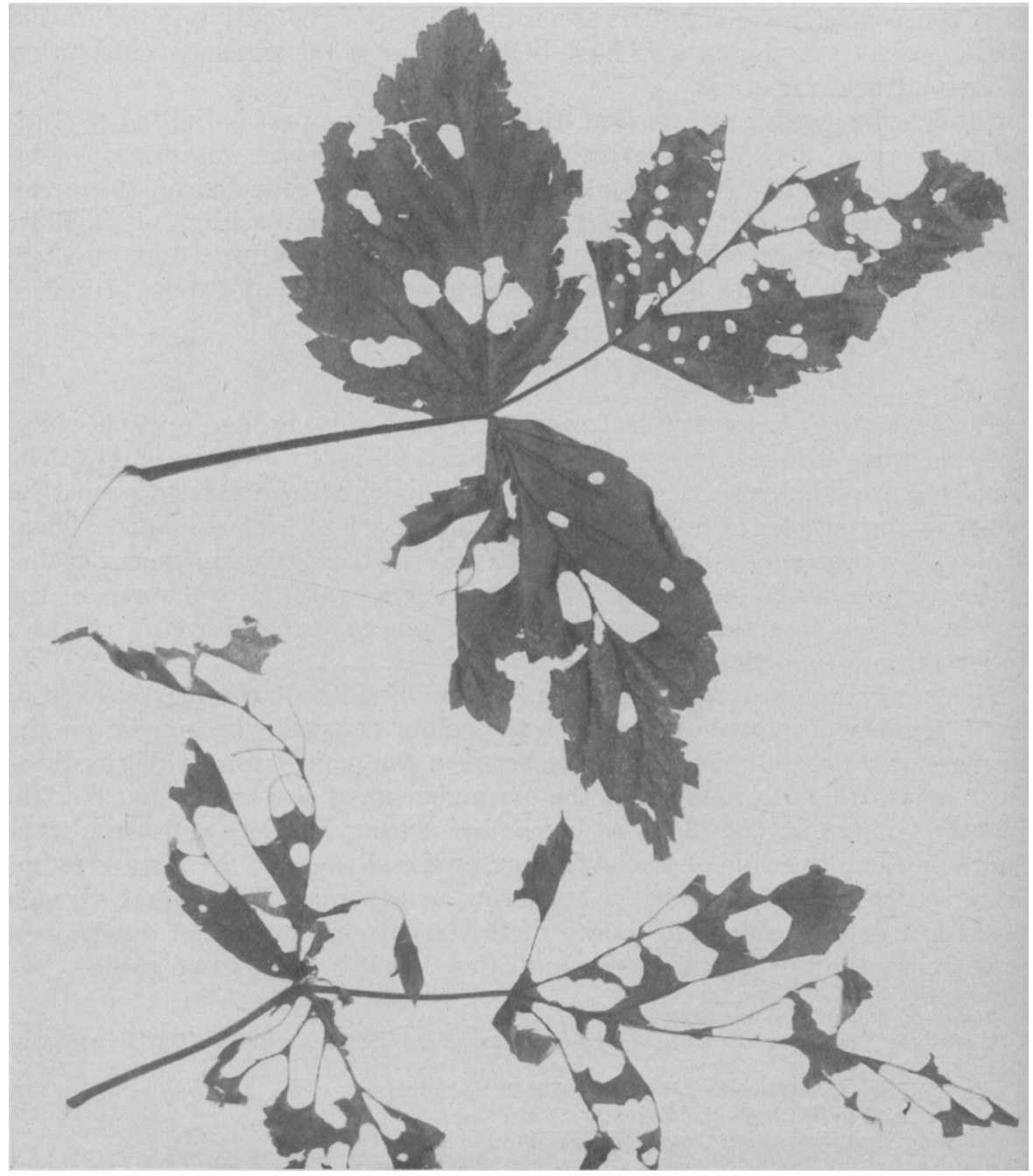

Fig. 2.-Raspberry leaves showing injury by the raspberry leaf sawfly. 
Mature larvae (fig. 3.) measure 10 to 12 millimeters in length. In diameter the head is smaller than the body, and has three large conspicuous black spots, one on either side and one on the vertex. A broad dark strip extends down the back of the larva. The rest of the body is yellowish white. There is a conspicuous row of tubercles along each side of the body. Although the body is sparsely covered with fine spines it appears nearly "hairless" to the unaided eye.

When the larvae are fully grown they crawl to the ground where they may travel a distance of 10 to 20 feet in search of a suitable place in which to pupate. Pupation usually occurs in wormholes in the highest, driest clods,

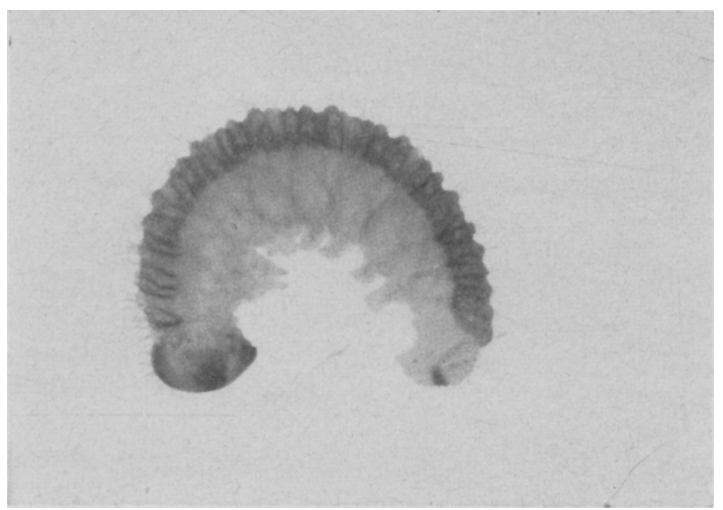

Fig. 3.-Larva of the raspberry leaf sawfly showing characteristic markings. (Five times natural size.)

although artificial sites, such as newspapers and stacked lumber (fig. 4) also offer suitable places.

The larvae spin cocoons in which to pupate. The cocoon consists of a sparsely woven outer structure apparently designed to support and protect the dense inner cylinder in which the larva lies. This inner cylinder is composed of a few threads over which is spread a continuous translucent film. When first constructed, the cocoons are pale yellow, but soon turn pale brown. They become darker with age, so that by spring, overwintered cocoons are chocolate colored. Cocoons of summer generations are empty before darkening can occur.

The length of the pupal period in midsummer was determined by placing mature larvae in battery jars in the laboratory. As soon as they commenced to spin a cocoon they were transferred to other jars and kept at room temperature. Under these conditions the length of time spent in the cocoon varied from 5 to 8 days. This is not the length of the true pupal period, however, since some time may be consumed by the larva in spinning the cocoon and resting before moulting to the pupa.

The adults (fig. 5) are shining black wasplike insects whose antennae, head, and body are shining black, and whose wings are transparent with brownishblack veins. The legs are mostly yellowish white. The antennae vary from 3.0 to 4.0 millimeters in length and the body varies from 5.0 to 6.0 millimeters in 
length. They fly readily on warm, sunny, still days. While they do not seem to be capable of making long-sustained, strong flights, they are probably able by means of several successive flights, to travel several miles.

At present this sawfly occurs in practically every raspberry patch throughout the central district of California. Such wide distribution has probably been achieved by flights of the adults. Natural distribution is also enhanced by the fact that all individuals in this species are females; or if males occur they are very rare. Fifty specimens collected at various places at various times were all females. Adults isolated in the pupal stage, which had no contact with

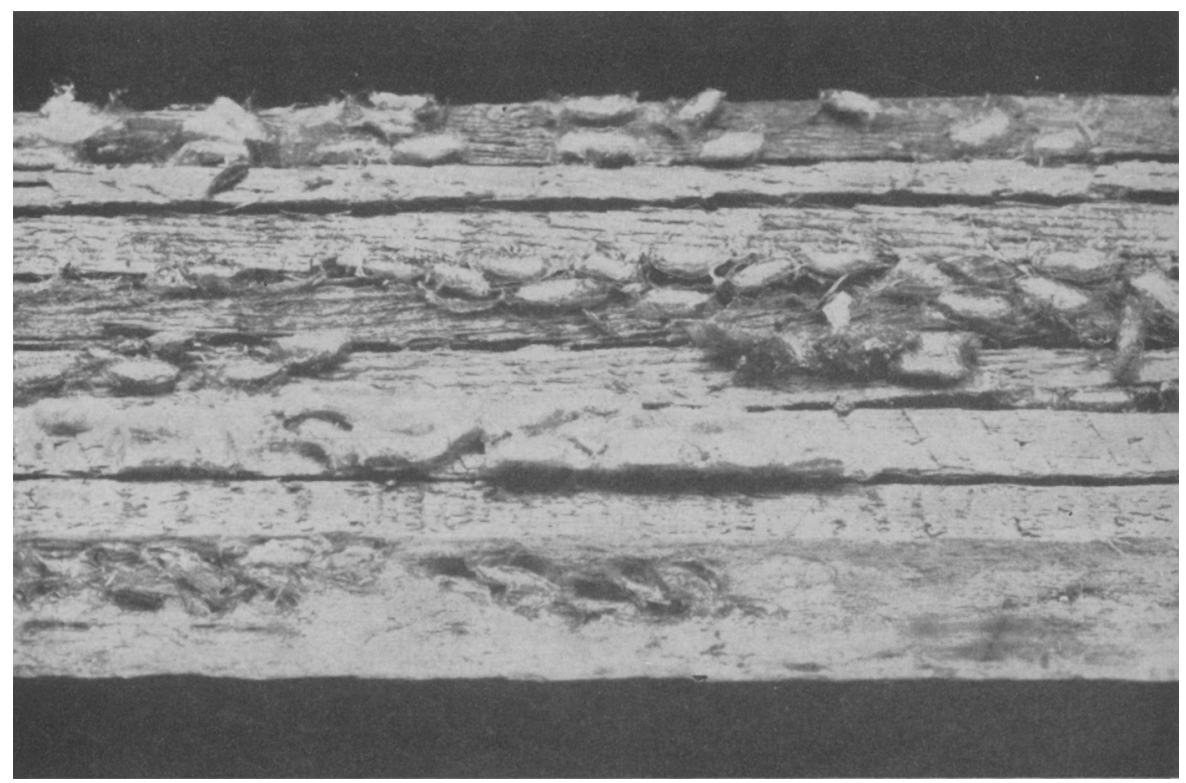

Fig. 4.-Cocoons of the raspberry leaf sawfly adhering to builders' lath stacked adjacent to raspberry bushes.

males, laid eggs which hatched normally. Females lay eggs within 24 hours after emerging from the cocoon. Adult life in the field is probably short. Adults in captivity lived only a few days.

\section{SEASONAL HISTORY}

The raspberry leaf sawfly overwinters as prepupal larvae and pupae in cocoons. The adults emerge from the cocoons during April and lay the eggs which give rise to the first brood of larvae. These larvae mature through May and early June. The first adults of the second brood appear about the middle of June. The second brood of larvae reaches a peak about the latter part of July and are nearly all pupated by the early part of August. A partial third brood of adults occurs about the middle of August, and the third brood of larvae occurs throughout September. Some of the larvae of each generation hibernate and emerge as adults the following spring. Hence, there may be 
three generations a year. A few feeding larvae found late in October, 1940, are believed to be the offspring of adults whose emergence from the pupae was delayed.

Those larvae which happen to pupate in cool places, such as deep shade or moist soil, probably do not emerge until the following spring, regardless of their generation or time of year. Pupae which were stored in a cool, shaded screened insectary, gave rise to adults after one month. If the temperature

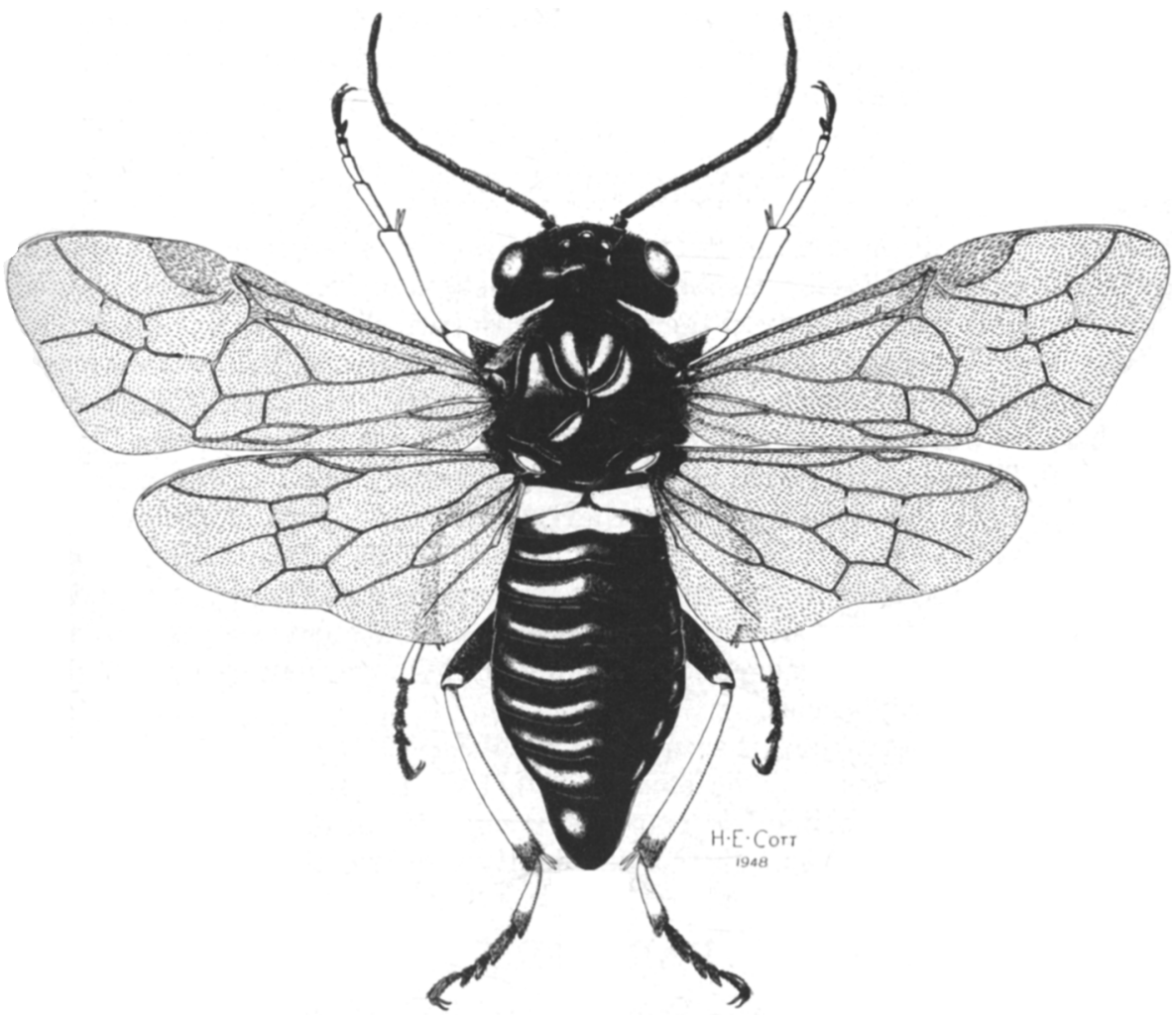

Fig. 5.-Adult female of the raspberry leaf sawfly, Priophorus rubivorus Rohwer.

(Twelve times natural size.)

had been slightly lower, these pupae would probably have carried through the winter. In Washington (Hanson, 1938) there is generally a single generation a year, but a few adults emerge and give rise to a partial second generation each year.

The larvae reach a peak of abundance and destructiveness in June, and decrease in abundance throughout the summer and fall. This means that the first or spring brood of larvae are the most destructive. This is probably due to the fact that a large proportion of each generation remains in the cocoon until the following spring, at which time they all emerge. The prolongation of the pupal period is probably the result of lower temperatures. To some extent the decrease in abundance of sawflies throughout the summer and fall may be due to parasitism. Either parasitic or climatic checks on this pest may occa- 
sionally be lifted, possibly causing an outbreak in the fall; but in the past twenty years, during which time the writers have had the pest under observation, the peak of abundance and injury has occurred in June.

The raspberry leaf sawfly varies greatly in abundance over a period of years. In occasional years in the central district it is so scarce that it is not a pest in any raspberry patch; but in other years it is abundant in all patches and seriously destructive in some. During the last twenty years it has reached three peaks of abundance: in 1928, 1933, and 1940. These outbreaks and recessions are believed to be caused by a fluctuating balance with the two species of parasite which are discussed in the section on parasites.

\section{HOST PLANTS}

In the central district the raspberry leaf sawfly is most commonly found on the Ranere (St. Regis) raspberry-the most extensively grown raspberry. In a few instances in the field the relative susceptibility of various brambles to attack was estimated. On one ranch, Ranere raspberries, Red Loganberries, and Himalaya blackberries were growing in contiguous patches. The Ranere raspberries were seriously defoliated, and the Loganberries were slightly damaged. The blackberries were not damaged to any appreciable extent, although some larvae were feeding on them. It seems likely that this sawfly can complete its life cycle on blackberry but does not do so by choice. On another ranch, Ranere raspberries, Cuthbert raspberries, and Youngberries were growing in contiguous patches. The Ranere and Cuthbert raspberries were severely and equally damaged. The Youngberries were damaged, but much less so than the raspberries.

From these observations it seems that raspberry is the preferred host, and that various varieties may be equally attacked. Loganberries and Youngberries are less susceptible but may suffer commercial damage, while blackberries are seldom, if ever, injured sufficiently to warrant control measures.

\section{PARASITES}

The raspberry leaf sawfly is heavily parasitized at times by two internal parasites : (1) a small fly, Bessa selecta (Meigen), and (2) a minute wasplike insect, Dibrachys boucheanus (Ratz). ${ }^{6}$ Pupae of the sawfly were found to be heavily parasitized by $B$. selecta in the fall of 1933 , following a serious outbreak of the sawfly that year. This parasite pupates within the skin of the sawfly inside the cocoon, and emerges as a small gray fly the following spring. It is world wide in distribution and attacks many species of sawflies.

The wasplike parasite, $D$. boucheanus (Ratz), is black, and the females measure about 2 millimeters in length. Both males and females occur, and the males are only about half as large as the females. After mating, the females oviposit in prepupal sawfly larvae within their cocoons. In the laboratory a generation of the parasite was completed in 12 days at room temperature. The parasites pupate inside the sawfly cocoon, but outside the larval skin of the sawfly. Usually from 20 to 25 parasites mature in each sawfly cocoon. The

'Determined by A. B. Gahan. 
parasites pass the winter as mature larvae within the sawfly cocoon. Pupation occurs in the spring, and the adult parasites emerge a few days later.

This parasite is world wide in distribution, and has been recorded as acting as a hyperparasite upon a number of other parasites. Whether or not it would act as a hyperparasite on $B$. selecta is not known, but laboratory rearings on sawfly larvae definitely known not to be infested with $B$. select $a$ have established the fact that $D$. boucheanus can act as a primary parasite on the sawfly larvae. Field evidence indicates that $D$. boucheanus is seldom, if ever, hyperparasitic on B. selecta.

\section{CONTROL}

The larvae of the raspberry leaf sawfly can be killed with a thorough application of a one half per cent rotenone dust. This will require from 50 to 75 pounds of dust per acre, depending on the size of the bushes. If no suitable power dusters are available the dust should be applied with a rotary knapsack type of duster. Dusters of the bellows type do not produce an even coverage on raspberries grown in a hedgerow system. The dust should be directed upward from below, in an attempt to blow dust on the undersides of the leaves, since the larvae are always found on the lower leaf surface. The dust should be blown particularly into the interior of the hedgerow since this is the favorite locality for the larvae.

Dusting should be done whenever damage by the larvae reaches economic proportions. However, growers should remember that the sawfly usually decreases in abundance after June, and dustings after this date will usually not be necessary.

\section{OTHER SAWFLIES ON RASPBERRIES}

The raspberry leaf sawfly should not be confused with two other species of sawflies occurring on raspberry foliage. These are : (1) the eastern raspberry sawfly, Blennocampa (Monophadnoides) ${ }^{7}$ rubi (Harris), and (2) the red sawfly, Tenthredo xanthus Nort."

Raspberry Sawfly. The name "raspberry sawfly" has been approved by the American Association of Economic Entomologists to represent B. rubi; hence, the name "raspberry leaf sawfly" is used herein to designate Priophorus rubivorus Rohwer.

The larvae of these two sawflies are easily distinguished, since $B . r u b i$ is pale green with white tufts of spines arising from body tubercles, arranged in rings around the body. This causes the larvae to appear quite "hairy" to the unaided eye. The larvae of $P$. rubivorus, on the other hand, appear almost "hairless" to the unaided eye. The adults of these two species are quite similar in appearance and can be positively identified only by a taxonomist.

The damage done by the larvae in feeding on the foliage of raspberries is likewise distinct in these two species. The raspberry sawfly (B. rubi) prefers to feed in the tops of the bushes on the young tender leaves, whereas the raspberry leaf sawfly ( $P$. rubivorus) feeds on the old leaves in the deepest shade

\footnotetext{
${ }^{7}$ The generic name Monophadnoides has been suppressed as a synonym of Blennocampa. (In a personal communication from E. A. Chapin.)
} 
in the center of the hedgerow. When the larva of the raspberry sawfly is disturbed (Flint, 1940), it raises its head and tail end of the body, whereas the larva of the raspberry leaf sawfly, when disturbed, curls its body into a spiral.

Distribution of Raspberry Sawfly. During the past few years, the raspberry sawfly (B. rubi) has been reported injuring raspberries in Connecticut, Idaho, Illinois, Kansas, Michigan, Montana, New York, Ohio, and Oregon. ${ }^{8}$ All of these states, with the exception of Kansas, are north of $40^{\circ}$ latitude. This might be taken as evidence that this sawfly is limited to northern states

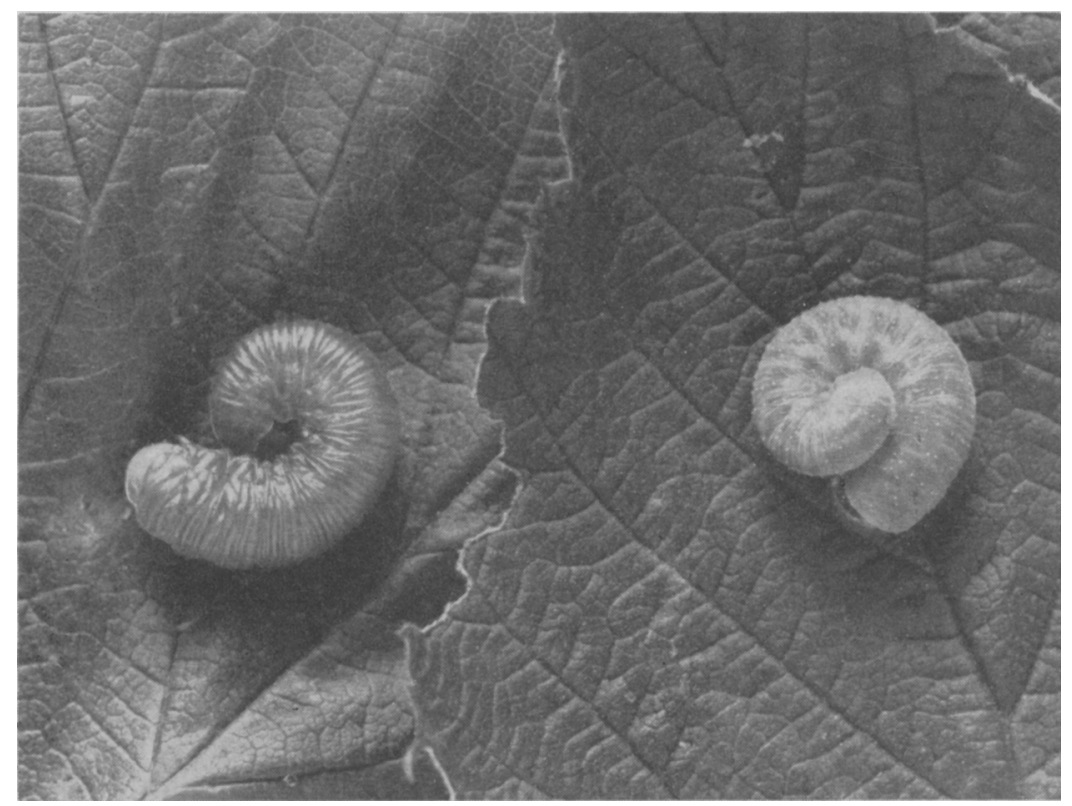

Fig. 6.-Larvae of Tenthredo xanthus Nort, ${ }^{4}$ showing typical resting position. Left, mature feeding larva; right, mature larva which has stopped feeding and is ready to pupate. Note ragged leaf edge caused by these larvae. (Two times natural size.)

in its geographic distribution. However, in 1930, the first 11 leading states in raspberry acreage were all north of $40^{\circ}$ latitude. Not once during the past twenty years when the writers have had frequent occasion to visit raspberry patches in the central district of California have specimens of the raspberry sawfly been found. It seems probable that this pest is not present in California.

Red Sawfly. Another species of sawfly occasionally occurs on raspberries in California. This species, which is herein called the red sawfly, Tenthredo xanthus Nort.," is of slight economic importance. During the past twenty years no infestation of this insect, which warranted control measures, has come to the attention of the authors. The adults are easily distinguished by their brilliant red and black coloring and their large size. The female is approximately one half inch long, with red body, legs, and head. The eyes and ocelli are black; the basal two joints of the antennae are red, and the rest of the antennae is black. The wings are blue black with a faint yellow spot on

${ }^{8}$ From notes by various reporters in the Insect Pest Survey Bulletin, 1934-1939. 
the front margin. The labrum and palpi are yellow. The thorax is black below, and a few irregular black blotches occur on the venter of the abdomen.

The larvae (fig. 6) are large pale green worms with minute white flecks on their bodies. They are almost devoid of hair. During the day they lie curled in a spiral on the upper surface of a leaf which is overlapped by another leaf.

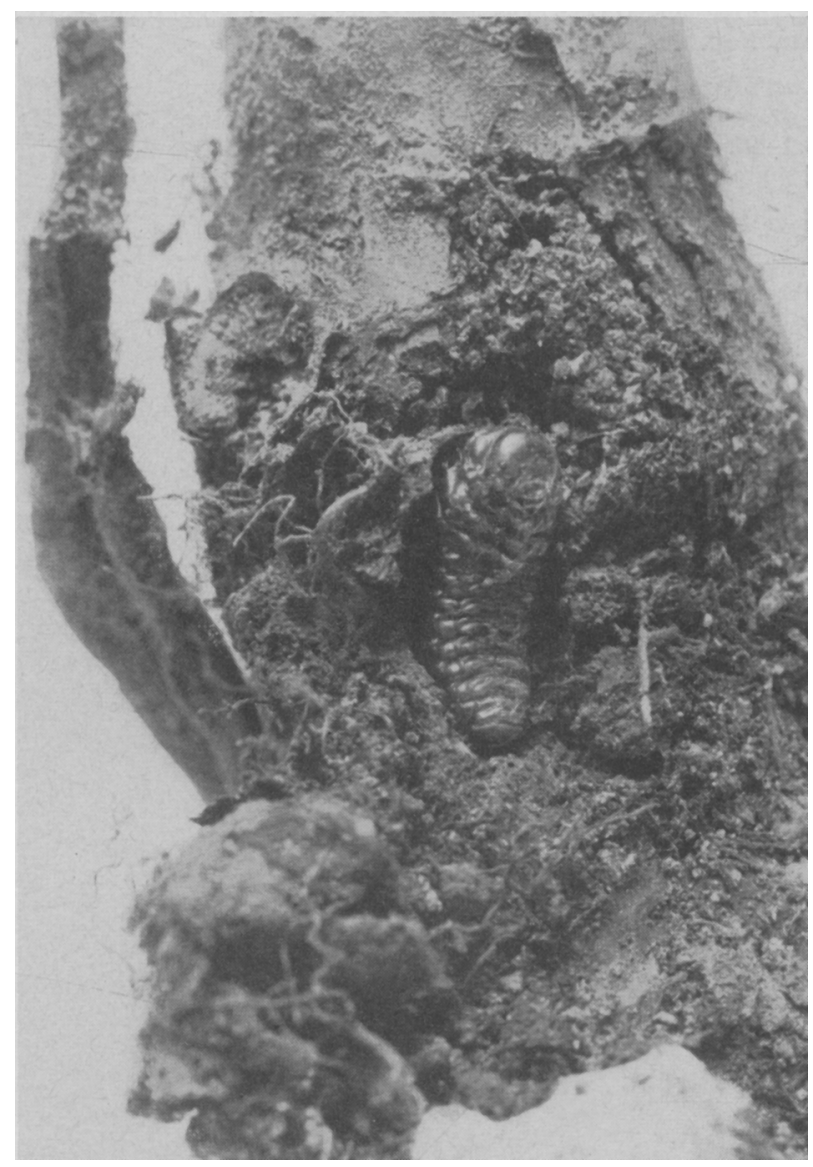

Fig. 7.-Raspberry crown showing prepupal and pupal chamber of Tenthredo xanthus Nort.4 (Two times natural size.)

Because of this habit and because of their coloration, they are very difficult to see. These larvae, unlike those of B. rubi and P. rubivorus, feed entirely on the edge of the leaf where they produce large irregular gaps in the leaf margin. When mature, the larvae drop to the ground and burrow into dead and rotted raspberry crowns, where pupation occurs (fig. 7).

Adults emerged in screen cages out of doors during the latter part of March, and were seen in the field until the end of April. By the middle of June, larvae in the field ranged from about half grown to fully grown. The winter is passed in the pupal or prepupal stage within the pupal cell. 


\section{LITERATURE CITED}

Flint, W. P.

1940. Bramble fruits, Part III. Bramble insects and their control. Illinois Agr. Exp. Sta. Cir. 508:1-71.

Hanson, A. J., AND R. L. Webster.

1938. Insects of the blackberry, raspberry, currant, and gooseberry. Washington Agr. Exp. Sta. Pop. Bul. 155:1-38.

RoHWER, S. A., AND WILLIAM MidDLETon.

1922. North American sawflies of the subfamily Cladiinae. U. S. Natl. Mus. Proc. 60 (1) :1-46. 


The journal Hilgardia is published at irregular intervals, in volumes of about 600 pages. The number of issues per volume varies.

Subscriptions are not sold. The periodical is sent as published only to libraries or to institutions in foreign countries having publications to offer in exchange.

You may obtain a single copy of any issue free, as long as the supply lasts; please request by volume and issue number from:

\section{Publications Office \\ College of Agriculture \\ Berkeley 4, California}

The limit to nonresidents of California is 10 separate issues on a single order. A list of the issues still available will be sent on request. 
â. 